\title{
Hledá člověk víc než sám sebe? Podněty Patočkova a Franklova pojetí lidského hledání smyslu k Maritainově integrálnímu humanismu na začátku 21. století s ohledem na nábožensko-pedagogické kladení otázek Ludmila Muchová a Petra Hořejší
}

\begin{abstract}
Anotace:
Článek dává do vztahu Maritainův výklad o integrálním křestanském humanismu v konfrontaci s humanismem materialistickým, člověkostředným, s myšlenkami filosofa J. Patočky a psychoterapeuta V. E. Frankla. Oběma byla společná hluboká zkušenost s totalitními režimy, které Maritain považoval za logické vyústění materialistického humanismu. Popis jejich myšlenek je doplněn kvalitativním výzkumem, který se týkal vnímání hodnot krásy, dobra a smyslu u současných mladých lidí. Diskuse nad jeho výsledky vede v kontextu uvedených myšlenek k formulaci nového vztahu křestananského humanismu k humanismu lidí bez křest’anské víry.
\end{abstract}

\section{Klíčová slova:}

Jacques Maritain, integrální humanismus, antropocentrický humanismus, Jan Patočka, Viktor Emanuel Frankl

\section{Úvod}

Křestané v naší zemi nemají ve společnosti na začátku 21. století jednoduchou pozici. Svým životním přesvědčením a životní praxí by měli svědčit o své víre. Je to víra, která z pohledu většinové společnosti může působit jako víra absurdní - svět, který vnímáme smysly, svět, jehož zákonitosti postupně rozkrývají přírodní vědy a současně tak přivádějí člověka k jeho ovládnutí, svět, jehož zdroje lze využít k blahobytu, o kterém se do dnešní doby žádné předcházející generaci ani nesnilo, tento svět není jedinou skutečností, která nás obklopuje. Vyvěrá ze svého zdroje, kterým je podle křestanské víry osobní Bůh. Před ním nese člověk odpovědnost za život a svět.

Proč to považujeme za „nejednoduchou pozici“? Jednoduše proto, že - jak se shodují někteří filosofové - postmoderní a postkřestanská většinová společnost žije v epoše, ve které křestanství už není všeobecným životním postojem lidí, protože v povědomí lidí Bůh bud’ „zemřel“ (jak to vyslovil Nietsche), nebo přinejmenším člověka „opustil“ (jak to formuloval Patočka).

Současně jsme jak ve filosofii, tak v sociálních vědách svědky analýz a zdůvodňování teorií, které toto období vidí jako období velmi krizové, protože lidé staví svůj život zejména na svých individuálních zájmech, které nemusí brát $\mathrm{v}$ potaz dobro většího celku, ztrácejí smysl pro objektivní měřítka, vycházejí pouze z vlastní subjektivity, která relativizuje každou všeobecně platnou 
hodnotu, orientují svůj život na materiální hodnoty postavené na vlastnění majetku a zážitků. Společnost se ocitá v krizi, má problémy nejen s předáváním biologického života - stárne a vymírá, ale i s předáváním osvědčených tradičních hodnot - řeší složité problémy eutanazie, interrupce, genového inženýrství, zbraní hromadného ničení...

Pro náboženského pedagoga může být taková situace výzvou. Jak vychovávat budoucí malé a mladé křestany, jestliže se pohybujeme v situaci zásadního zpochybňování pravdivosti křestanské víry - my jako vychovatelé i děti jako generace, kterou máme za úkol vychovat? A to v době, kdy současně zažíváme důsledky společenského vývoje, který tolik odborníků vnímá jako krizový? Nechceme-li mladou generaci vést $\mathrm{k}$ ohraničování se od zbytku světa, $\mathrm{k}$ vytváření ghett, ve kterých si malé skupinky křestanů vytvoří skanzen tradičního křestanství bez nároku na prokvašení celého světa kvasem evangelia, musíme vzít kontext společnosti, ve které žijeme, vážně a vážně se také ptát, co vlastně lidé, kteří žijí s vědomím „smrti“ Boha či „opuštěnosti“ Bohem, zažívají vzhledem $\mathrm{k}$ transcendenci. Jsou zcela zaměřeni pouze na materiální svět a materiální hodnoty, nebo i oni věrni svému lidství - hledají víc než jen sami sebe, svůj užitek a svoje pohodlí?

Náboženský pedagog tedy musí teorie křestanských i nekřestanských filosofií zabývajících se člověkem nejen znát, musí je rovněž podrobit empirickému zkoumání, aby ověřil jejich platnost $\mathrm{v}$ praxi. V tomto článku se proto chceme zabývat filosofickým myšlením J. Maritaina, křestanského myslitele, který filosoficky propracoval vztah křestanství a humanismu a vyvodil z nich výzvu k uskutečňování nového, integrálního křestanství, které postavil do protikladu s humanismem antropocentrickým, vrcholícím v totalitních režimech 20. století. Vycházel přitom z filosofie Tomáše Akvinského. Myšlenky křestanského humanismu vymezoval především proti ateismu totalitních režimů. $\mathrm{V}$ totalitních režimech fašistických a komunistických však paradoxně rozvíjeli své pojetí humanismu autoři, kteří nevycházeli z křestanství, nelze je ovšem ani považovat za zastánce antropocentrického ateistického systému směřujícího $k$ totalitní katastrofě. Naopak, právě uprostřed těchto režimů formulovali svoje humanistické myšlenky, které se od těch totalitních zásadně lišily. Zvolili jsme dvě velmi výrazné postavy 20. století: V. E. Frankla, zakladatele 3. vídeňské psychoterapeutické školy a pro české myslitelské prostředí charakteristického J. Patočku. Oba měli velmi blízko k existenciální filosofii. Teprve na tyto myšlenky naváže empirická výzkumná otázka: Vnímají mladí lidé ve svém volném čase hodnotu životního smyslu a s ním spojené hodnoty dobra a krásy, které je samé přesahují? Jestliže ano, lze člověka překračujícího sama sebe ze své vnitřní síly a vztahujícího se k hodnotám mimo sebe samého nazvat antropocentrickým, a tudíž mýlícím se? Závěry kvalitativního výzkumu, o kterém zde chceme referovat, se potom mohou stát východiskem pro lepší chápání cílů a úkolů současné náboženské výchovy mladých křestanů vyrůstajících $\mathrm{v}$ atmosfére všeobecného odklonu většinové společnosti od křestanství a křestanského stylu života.

\section{Maritainovo pojetí humanismu jako směřování člověka $\mathrm{k}$ absolutnímu smyslu v Bohü}

Humanismus Maritain definuje následovně: „... Humanismus tíhne svou podstatou $k$ tomu, aby učinil člověka pravdivěji lidským a zjevil jeho pưvodní velikost, poskytuje mu účast na všem, co ho může obohatit $v$ př́rodě $i v$ dějinách, žádá však zároveñ, aby člověk rozvíjel možnosti $v$ sobě

1 Na tomto místě popíšeme základní rysy Maritainova humanismu. Nebudeme se hlouběji zabývat určujícími principy jeho filosofie, které vycházejí důsledně z aristotelsko-tomistické tradice. Na některé z nich (např. na otázku přirozenosti člověka, svobody lidské vůle nebo konečného cíle lidského života, jak je můžeme nalézt např̀ v díle Jacques MARITAIN, The person and the common good, Indiana: University of Notre Dame Press, 2002 nebo Jacques MARITAIN, Odpovědnost umělce, Praha: Triáda, 2011) narazíme v části textu, která se zabývá diskusí kvalitativní empirické studie. 
obsažené, své tvůrčí síly a život rozumový, i aby se pilně snažil učinit ze sil fyzického světa nástroje své svobody. " ${ }^{2}$ Naznačuje, v čem spočívá náboženský rozměr tohoto pojmu, a sice, že v člověku je něco, „co směruje nad čas, nějaká osobnost či osoba, jejiž nejhlubší potřeby přesahují všechen řád vesmíru“. Cituje přitom Aristotela: „Ukládat člověku jen lidské, tot zrazovat člověka a chtít jeho neštěstí, nebot hlavní částí sebe, což jest duch, jest člověk povolán $k$ čemusi většímu než $k$ životu pouze lidskému. “" Jinak řečeno, podle Maritaina každý člověk zaujímá svůj vlastní postoj k životu a v jeho intencích se také $\mathrm{v}$ životě nějak chová, at je či není spjat s nějakým konkrétním náboženstvím nebo s konkrétní filosofií.

Logicky proto Maritain rozeznává dva typy humanismu: humanismus antropocentrický a humanismus teocentrický. Pomocí dlouhé myšlenkové úvahy dovozuje, v čem mezi nimi spočívá zásadní rozdíl:

Teistický humanismus je podle něho skutečně křestanský humanismus. Když totiž pátrá po středu osobnosti člověka, dospívá k Bohu, který svou milostí vykupuje sice svobodného, ale hříšného člověka. Zatímco antropocentrický humanismus postavil podle Maritaina do středu člověka tohoto člověka samotného. I zde je sice konstatována lidská svoboda, ale v jejím naturalistickém pojetí: člověk je svobodný sám ze sebe, nikoliv díky Boží milosti, která ho osvobozuje a ke svobodě vykupuje. Podle Maritaina spočívá právě v této skutečnosti - v člověkostřednosti - základní omyl sekulárního humanismu.

Maritain to ukazuje na třech aspektech - na pohledu na jednotlivého člověka, na kulturu a na Boha. $\mathrm{V}$ pohledu na jednotlivce Maritain především ukazuje, jak díky racionalismu 18. století začal člověk sám sebe hodnotit jako velmi vznešenou bytost, která sama sobě klade zákony a je bytostně dobrá. Vítězství darwinovských myšlenek, které samy o sobě nejsou v rozporu s křestanskou vírou, však znamenalo v povědomí racionalismu neuznání „metafyzické diskontinuity“. V takovém schématu není místo pro okamžik vzniku nové duchovní bytosti s Bohem stvořenou duší, která je vržena do bytí, aby zde naplnila Stvořitelem daný věčný úděl. A například Freudovo učení, že lidské vědomí není nic jiného než hříčka sil pulsujících mezi instinktivní vrstvou člověka a normami společnosti, které během života zvnitřnil, tuto původní velikost člověka paradoxně proměnilo v bytost, která pouze zakrývá svou závislost na vlastních pudech.

Něco podobného se podle něj odehrálo i v evropské kultuře jako celku. Ta nejprve coby plod renesance oddělila pozemský časný svět od světa pečujícího o věčnost, ale prozatím zůstala křestanská. $\mathrm{V}$ dalších staletích se však tyto dva světy v životě lidí začaly více a více oddělovat. A člověk, oproštěný od „pověry“ zjeveného křestanského náboženství, vyslovil požadavek ovládnout př́rodu zcela ve svi̊j prospěch, aby mohl do sytosti užívat časných dober. A vše nasvědčovalo tomu, že se mu to díky rozvoji lidského rozumu podaří v podobě rozvoje věd, techniky a technologií. A protože tím člověk postupně začal svůj poslední cíl vkládat pouze sám do sebe, dospěl ve 20 . století k ideologii materialismu a komunismu, podle níž může člověk dospět pravé svobody pouze jako člověk kolektivistický.

Idea Boha prošla podle Maritaina též tragickým vývojem. Descartes podle něho svými úvahami o geometrickém lidském rozumu vyloučil, že by člověk mohl nahlížet pomocí myšlenkových analogií do Božího tajemství, i když Bůh v jeho pojetí byl jakýmsi „ručitelem“ lidského rozumu, byl tímto rozumem naprosto nepoznatelný. V dalších staletích jiní filosofové (např. Leibnitz) ukazovali, že dokonalost umělce je možno poznat pouze podle dokonalosti jeho uměleckých děl, a to i Božského umělce. Ale Bůh se již stává pouze ideou, lidskou představou, která sama nemůže nic

2 Jacques MARITAIN, Integrální humanismus, Řím: Křestanská akademie, 1967, s.10.

3 Tamtéž, s. 9 a 10. 
rríci o skutečném Bohu. A tuto představu lze snadno umlčet nebo zabít. To podle Maritaina vykonal Nietsche, když ve známém podobenství o bláznovi na tržišti zvěstoval „smrt Boha“.

Lidstvo tak podle Maritaina dospělo do slepé uličky, v níž byl člověk, na začátku renesance oslavovaný pro svou jedinečnost, velikost a dokonalost, během několika staletí zotročen a znevážen, až dospěl do života v podobě sovětské komunistické totality, která opřela svoji krutovládu o předpoklad, že neexistuje Bůh, a neexistuje-li, neposvěcuje ani srdce a jádro člověka, který je tak povolán, aby uskutečnil sám ze své kolektivní síly ráj na zemi. Maritain se domnívá, že tragické události 20. století, které přinesly neuvěřitelnou míru blahobytu na jedné straně, ale též neuvěřitelnou míru lidského násilí, bolesti, utrpení a smrti, přesvědčují dostatečně jasně o tragickém rozpojení Boha jako centra lidské bytosti a tohoto člověka, protože po něm následovalo jen postupné vykázání Boha do sféry představ lidského rozumu, aby byl posléze jako pouhá lidská myšlenka zničen. Antropocentričnost - člověkostřednost humanismu se mu tak jeví jako nenápadná past, $\mathrm{v}$ níž člověk může uvěznit a zničit sám sebe.

Maritain na základě této analýzy nabízí svou koncepci integrálního humanismu. Integrálním ho nazývá proto, že člověk $\mathrm{v}$ něm vidí svůj úděl $\mathrm{v}$ cíli orientovaném na věčnost a Boha, jehož může analogicky, nedokonale, ale přece jen nahlí̌zet, a přitom uskutečňovat své možnosti tvořivě v Bohu, který je „absolutní možností všech možností“. Historicky se tyto možnosti člověku nabízejí a otevírají okamžikem Vtělení, v Kristu, a to trvá a pokračuje v církvi. Autonomie světa a člověka nevylučuje Boha jako absolutní Bytí, ale naopak, předpokládá ho, rodí se s něj a vrací se $\mathrm{k}$ němu. A Bůh neztrácí svou nekonečnost a plnost, jestliže dává člověku účast na své vlastní nekonečnosti a plnosti. Tak člověk dospívá $\mathrm{k}$ jednotě a míru, které přesahují veškeré tušení. Maritainovo pojetí křestanského humanismu uvádí člověka do souladu mezi milostí a přirozeností, vírou a rozumem, teologií a filosofí, nadpřirozenými ctnostmi a přirozenými dokonalostmi, duchovním řádem a časným pořádkem světa, spekulativní teoretickou rovinou a rozměrem praktické činnosti, mystickou kontemplací a vědeckým hledáním, věrností věčným skutečnostem a schopností porozumět času. ${ }^{4}$

\section{Patočkova úvaha představující humanismus jako vědomí lidské odpovědnosti za hledání „problematického smyslu“}

Logika Maritainových filosofických úvah je srozumitelná na pozadí válečných událostí 20. století na velké části Evropy, které vyústily do vzniku panství komunistické ideologie a posléze ideologie nacistické. Proto Maritain zcela logicky konfrontuje křestanství především s ní. Roky života uvnitř jedné z nich však přinesly nečekanou odpověd’ českého filosofa J. Patočky.

V Kacířských esejích Patočka analyzuje komunistickou doktrínu o nutnosti neustálé války za světový mír. Vychází přitom $\mathrm{z}$ reality dvou zničujících světových válek ve 20. století. Přes svou ničivost může mít válka i moc vracet člověka $k$ otázce smyslu života. Ideologie sice přesvědčují lidi ve jménu „sil dne“, že válka je krutá, ale nutná, aby po ní př̀ǐla spravedlnost a mír pro budoucí generace, jejich štěstí. Proto je potřeba se nyní obětovat - dát své vlastní štěstí za štěstí budoucích generací. Válka však v sobě nese podle Patočky také jinou zkušenost. Může se stát výzvou $\mathrm{k}$ duchovnímu růstu člověka. Patočka ho popisuje jako děj odehrávající se v několika etapách. $\mathrm{V}$ první etapě zažívá člověk nesmyslnost a nesnesitelnost válečného běsnění, jeho absurditu. Je to

4 MARITAIN, Integrální..., s. 33-39 a s. 292-295. Také Ludmila MUCHOVÁ, Autenticky žitá víra ve svobodné pluralitní společnosti a náboženská výchova, Autentická sloboda a viera. Zborník monografických štúdií, ed., Andrea BLAŠČÍKOVÁ, Peter KONDRLA, Nitra: Unvierzita Konštantína Filozofa v Nitre, 2011, s. 38-54. 
zkušenost, která člověkem otřese. Tím se však stane snadnou obětí propagandy, která volá po neutuchající „válce za mír“. Ze společnosti se tak stává věčné bojiště, které dovoluje používat zbraní jako je demagogie, podezírání, pomluvy. Požadovány jsou oběti za budoucí mír. Jenže zkušenost fronty nebo totální moci je zkušenost definitivní a absolutní. Člověk porozumí nakonec tomu, že obět vlastního života má význam sama v sobě, nikoliv jako prostředek pro štastnou budoucnost jiných, nýbrž jako zisk vlastní absolutní svobody, která je nezávislá na zastrašování mocných. Vrchol života spočívá ve „vydání se“. Je to život, v němž člověk už dávno před tím směřoval k jeho vrcholu, obět je jeho logickým vyústěním. Tímto vrcholem je výzva, aby člověk realizoval proměnu celého svého života, celé své existence. Znamená kosmičnost a univerzálnost, ke které člověk dospěl absolutní obětí sebe a svého „dne“. Smrt je obět’, která provází svobodný čin člověka bez ohledu na strach ze smrti, který v něm opakovaně burcují mocní, a to pro absolutní svobodu jako takovou. Protože právě strachem ze smrti je člověk poután k životu, a tím se stává nejvíce manipulovatelným. ${ }^{5}$

Chvatík upozorňuje, že myšlenka autentické oběti nemá u Patočky původ v křestanství, protože v textu Meditace po 33 letech přirovnává Patočka obět Krista ke smrti Sókrata. Oba se obětovali, aby se ukázalo, že lidský život je plně lidským, teprve když dovede vazbu na pouhý život překonat, když dovede žít nad úrovní pouhé úživy, když dovede žít ve vzmachu. Oba byli dokonale pravdiví. A svým vystoupením, svou snahou pečovat o duši zaútočili na vše, co vládne světem upadlé pouhé starosti o život. Proto jsou odsouzeni a zahubeni. Oba se mohli násilné smrti vyhnout, ale oba ji dobrovolně přijali. A u obou je tento obětovaný život spojen s myšlenkou nesmrtelnosti. V tom totiž spočívá smysl třetího pohybu: totiž, že člověk prolomí úroveň pouhého života a otevře se dimenzi, která není ničím jsoucím, ale svět jsoucích věcí podmiňuje. ${ }^{6} \mathrm{Na}$ jiném místě Patočka charakterizuje pravou obět jako „výkon, ve kterém jde o to, aby se bytí jako takové ukázalo jako to, co vládne a pro co jsem ochoten a musím jít až do krajnosti, kterou mi historická situace diktuje a kterou já prijímám. "

Důsledkem postoje připravenosti k oběti vlastního života kvůli vlastní svobodě je skutečnost, že nepřítel již není absolutní překážkou na cestě k míru. Není tím, kdo musí být odstraněn ve jménu pokroku. Je spoluúčastníkem téhož otřesu - otřesu způsobeného po dosažení téhož vrcholu absolutní svobody v absolutní vydanosti. Člověk tak zažívá „solidaritu otřesených“, kteří dokážou vyslovit modlitbu za nepř́itele a milovat i ty, kteří je nenávidí. ${ }^{8}$ „Nejhlubším objevem fronty je tedy tato vykloněnost života do noci, boje a smrti, neodepsatelnost této položky v životě, která se zdá z hlediska dne pouhou neexistencí. "P Proměna onoho absolutního životního smyslu, který zde škobrtne o nic, tedy o zjištění, že Bůh bud' není, nebo člověka opustili1 ${ }^{10}$, vyvolá v člověku zděšení a otřes, člověk tak překročí nepřekročitelnou hranici, v níž se všecko mění. ${ }^{11}$ Dějiny lidstva jsou konfliktem pouhé úživy (péče o holé přežití a spoutanost strachem o holý život) se životem na vrcholu, který neplánuje budoucí všední dny, ale ví, že všední den, jeho život a „mír“ mají svůj

Srov. Jan PATOČKA, Kacírské eseje o filosofii dějin, Praha: ACADEMIA, 1990, s. 132-137.

6 Srov. () Ivan CHVATÍK, Zodpovědnost „otřesených“: Patočkova „péče o duši“ v době „poevropské“, Centrum pro teoretická studia (online), s. 8, dostupné na: http://www.cts.cuni.cz/soubory/reporty/CTS-09-05.pdf, citováno dne 6. 6. 2018.

7 Jan PATOČKA, Př́loha II. Přednášky a semináře, Péče o duši III, Praha: OIKOYMENH, 2002, s. 421.

8 Srov. PATOČKA, Kacířské eseje..., s. 138. (Srov. @ Zuzana SVOBODOVÁ, Pojetí bratrství u Jana Patočky, Envigogika: Charles University E-journal for environmental Education 2017/XII/2, s. 2, (on-line) dostupné na https://doi.org/https://doi.org/10.14712/18023061.556, citováno dne 16. 6. 2018.)

9 Tamtéž, s. 138.

10 Srov. též PATOČKA, Péče o duši..., s. 413. Patočka na tomto místě dává za příklad skutečné oběti obět Krista, kterou spojuje právě s jeho zvoláním na kříži: Bože můj, Bože můj, proč jsi mě opustil. Za pravou obět považuje pouze takovou, ve které není ztráta života chápána pouze jako „výměna jsoucen“, ale jako setkání se s bytím.

11 Srov. PATOČKA, Kacírské eseje..., s. 138. 
konec. Pouze ten, kdo to pochopí, je schopen obratu, metanoiy, je duchovní člověk. ${ }^{12}$ Jak zdůrazňuje Chvatík, dějiny se tedy podle Patočky odehrávají tam, kde člověk usiluje o vzestup, „Vzmach“ nad úroveň pouhé úživy, byṫ by tato úživa spočívala v oddávání se všem dokonalým technickým a technologickým vymoženostem. Odehrávají se tam, kde člověk směřuje $k$ vrcholu vlastního života, kde poodkryje tajemství bytí, tedy to, co pouze tuší, čeho se nemůže dotknout, co ale podmiňuje svět $s$ jeho zákonitostmi. Člověk už nedisponuje absolutním smyslem daným Bohem, ale smyslem. Úkolem člověka je osvědčit svou odpovědnost za to, co dobrého v takové situaci může udělat, aby byl smysl nalezen či odhalen, byt riskuje opakované a více či méně zdařilé pokusy. Zodpovědnost za toto tápavé hledání smyslu směřuící k vrcholu schopného i oběti vlastního života nese člověk žijící bez víry v Boha (a jím člověku uložený absolutní smysl) sám před sebou a před ostatními lidmi. ${ }^{13}$

Rozumíme zřejmě dobře, že takto chápaný úkol člověka ve světě lze těžko nazvat „antropocentrickým“. Je to daleko spíše výzva k vědomí vydanosti člověka tajemství skrývajícím se za existencí člověka a světa, které tváří v tvář utrpení a zlu nemůže nazvat milujícím Bohem, které ho ale s o to větší naléhavostí staví před otázku jeho odpovědnosti za naplnění života smyslem, byt tváří v tvář nicotě, která se tak před ním otevírá tváŕí v tvář tajemství bytí.

\section{Franklovo pojetí humanismu jako mravní hledání jedinečného smyslu v jedinečné situaci}

Druhý zvolený autor - V. E. Frankl - formuloval své základní výpovědi o člověku ve vztahu k podstatě jeho lidství v dialogu se dvěma psychoterapeutickými školami: Freudovou psychoanalýzou a Adlerovou individuální psychologií. I Frankl formuloval základní výpovědi své teorie uprostřed vlády brutální totality - jako Žid v koncentračních vyhlazovacích táborech, výplodech německé národně socialistické strany. Popsal lidskou vůli naplnit život smyslem jako základní faktor, který u vězňů zásadním způsobem ovlivňoval jejich vưli k životu. Uprostřed marasmu, který Maritain popsal vedle sovětského komunismu jako druhý příklad tragického vyústění ztráty Boha ve vědomí lidí konce 19. století, vyslovil následující tézi: Zdravý člověk neusiluje ve svém životě o vlastní štěstí, ale o naplnění vlastního života smyslem. Rozpoznává tři roviny tohoto naplnění:

1. jedinečný smysl jedinečné situace v životě člověka;

2. smysl života;

3. smysl celku světa.

Výzva naplňovat život smyslem plyne podle Frankla prostě z faktu lidské existence, z toho, že člověk je schopen promýšlet jednotlivé okamžiky života a volit z možností, které se nabízejí k jejich vyřrešení. To je výsledkem úvahy, kterou člověk učiní ve svém nitru a poté uskuteční. Smysl v životě tedy není dán žádnou lidskou vírou, ale tím, jak člověk utváří svưj život, a to především v každé jedinečné situaci. Člověk, který by usiloval pouze o svou vlastní duševní rovnováhu nebo homeostázu, by ztrácel cosi podstatného ze svého lidství.

Smysl života jako celku následně rozkryjeme až v jeho samotném závěru, podobně jako když uvažujeme o smyslu filmu až po jeho zhlédnutí. Ale abychom mu porozuměli, musíme před tím rozkrýt i smysl jednotlivých obrazů, tedy jednotlivých životních situací. Celý život, celou svou

12 Srov. tamtéž, s. 141.

13 Srov. (c) CHVATÍK, Zodpovědnost..., s. 7-10. 
existenci, říká Frankl, musíme vnímat jako otázku. To život se nás ptá, jak se v konkrétních situacích zachováme. Je věcí naší odpovědnosti, jakou dáme odpověd', a to odpověd'v podobě konkrétního činu, i v případě, že jde např. tváří v tvář bolesti a utrpení o niterný čin přijetí či nepřijetí. Odvolává se na Yehudu Bacona, podle kterého utrpení a zlo v Osvětimi mělo pro trýzněné smysl pouze v případě, jestliže je změnilo, jestliže vedlo k jejich duchovnímu růstu a zrání. ${ }^{14}$

Porozumění smyslu světa jako celku je oproti tomu rozhodnutím člověka pouze vaktu, ve kterém se rozhoduje pro víru, v tom, že uzná existenci a autoritu Boha jako zdroje a posledního garanta smyslu, nikoliv tedy ve vlastních činech. V rozhovoru se židovským myslitelem Lapidem rozvíjí Frankl Lapidovo upozornění, že čin, kterým uskutečňujeme smysl, se obrací vlastně do budoucnosti: činíme to, co v budoucnosti osvítí tuto situaci jako smysluplnou. Vysvětluje, že výrok Ježíše „Bože můj, Bože můj, proč jsi mě opustil?“, který celé generace teologů chápaly jako výraz pochybnosti o existenci Boha (a viděli jsme, že tomu tak bylo i u filosofa Patočky), byl překládán nepřesně. V hebrejském originále znamená nikoliv prosté „proč“, ale „pro co“, „kvůli čemu“, Ježíš tuto otázku vyslovil jako výraz touhy porozumět smyslu svého utrpení. Bůh je naopak akceptován, je předpokládán i smysl utrpení, trpící však prosí o náznak, proč mu bylo utrpení uloženo. ${ }^{15}$ Frankl považuje vztah těchto tří různých rovin, v nichž člověk usiluje o naplnění života smyslem, ke křestanskému chápání smyslu světa za vztah inkluzivní. Náboženský rozměr života podle něho překračuje rozměr antropologický v tom smyslu, že je to rozměr širší, který v sobě obsahuje antropologický rozměr jako dimenzi užší. Takže tyto dva rozměry se navzájem nevylučují, ale jeden je obsažen v druhém, je inkludován. Problém tedy není např́ílad formulován tak, že ti, kdo považují za posledního garanta správnosti svých činů svědomí, se ocitají v přímém protikladu vůči těm, kteří ho vidí jako nejvyšší Boží instanci. Boží autorita, která stojí za principy dobra a zla, které může člověk uskutečnit, spíše sahá daleko až za svědomí. Člověk při rozhodování, jaký čin je v určité situaci ten nejsmysluplnější, vede rozhovor se svým svědomím. Věřící člověk věří, že právě v něm vede rozhovor s Bohem. Frankl tedy nevnímá vztahy mezi věřícími křestany podobně výlučně - exklusivisticky - jako Patočka, pro kterého se svědomí stává nejvyšší instancí pro mravní rozhodování v okamžiku, kdy se člověk cítí být Bohem opuštěn. Mezi svědomím a Boží autoritou podle Frankla existuje vztah inkluze: svědomí může být viděno současně jako nejvyšší lidská instance smyslu, ale také v hlubším záběru jako výraz principů garantovaných samotným Bohem. ${ }^{16}$

Jak Patočkovy, tak Franklovy humanistické myšlenky mají společné rysy. Jednak jsou již reakcí na hlubokou krizi lidství, kterou dva totalitní režimy v Evropě 20. století přinesly. Maritain je zdůvodňuje odklonem člověka od duchovních zdrojů vlastní existence - od svého Tvưrce, který se člověku zjevil v Ježíši Kristu a který jej na cestě životem posiluje silou Ducha svatého. Patočka je př́ikladem člověka, který se cítí Bohem opuštěn, ale přesto se nenechá oklamat tlakem totalitní moci, nepodléhá strachu, zažívá se ve své svobodě, jejímž vrcholem je schopnost obětovat svůj život jako vyvrcholení své solidarity s trpícími lidmi, bez vize společenství člověka s Bohem. Frankl - sám zbožný Žid - vnímá duchovní hledání lidí, kteří nesdílejí náboženskou víru, a přesto jsou schopni naplnit svůj život smyslem tím, že jej orientují na hodnoty, které leží mimo jejich egocentrické potřeby či zájmy. Takové duchovní úsilí může mít náboženský obsah a plynout

14 Vzhledem k rozsahu této studie můžeme pouze odkázat na českou sekundární literaturu, která rozvíjí Franklovy myšlenky: Martina KOSOVÁ a kol., Logoterapie: existenciální analýza jako hledání cest, Praha: Grada, 2014; Peter TAVEL, Smysl života podle V. E. Frankla: potřeba smyslu života, přinos V. E. Frankla k otázce smyslu života, Praha: Triton, 2007; Miloš RABAN, Duchovní smysl člověka dnes: od objektivního k existenciálnímu a věčnému, Praha: Vyšehrad, 2008.

15 Srov. Viktor Emanuel FRANKL, Pinchas LAPIDE, Hladanie Boha a otázka zmyslu, Bratislava: LÚČ, 2009, s. 34-35 a s.108-114.

16 Srov. tamtéž, s. 46. 
z hluboké víry, avšak také nemusí. Tito autoři, zdá se, popsali duchovní rovinu lidské existence, kterou objevuje člověk „na dně svých sil“. Není to člověkostředná snaha o vlastní štěstí, je to hledání problematické, trpělivé, ale hluboce pravdivé. Osobnost, která jde po takové cestě, integruje do svého duchovního hledání kategorii životního smyslu, který je naplněn vždy, když se člověk setká s hodnotami přesahujícími jeho samého (vedle bolesti a utrpení to pro Frankla byly také hodnoty tvůrčí a hodnoty zažívané jako láska nebo krása). Kdybychom tedy Maritainovo pojetí humanismu nazvali integrálním humanismem křestanským, mohli bychom myšlenkové koncepty Frankla nebo Patočky nazvat integrálním humanismem duchovním, spirituálním, v němž se člověk otevírá hledání hodnot, které jeho samého přesahují. Takže se vydává na cestu, která má svůj vrchol v jejich absolutním vyjádření v Bohu (Bůh Stvořitel, Bůh - krása, Bůh - láska, Bůh trpící spolu s člověkem v Ježíši Kristu).

Zbývá otázka, zda je i člověk žijící v evropské společnosti na začátku 21. století schopen vnímat hodnoty, které by byly s to kritéria životního smyslu naplnit, aby se s jejich pomocí mohl vydat na cestu vedoucí za svou vlastní člověkostřednost. K náznaku odpovědi jsme v roce 2018 provedli kvalitativní výzkum, pro který jsme zvolili hodnoty vnímání krásy, dobra a samotného smyslu života.

\section{Kvalitativní výzkum vnímání hodnot krásy, dobra a vyššího smyslu lidmi mladé dospělosti ${ }^{17}$}

Cílem výzkumu bylo zjistit, zda jsou lidé ve věku mladé dospělosti (od dvaceti do třiceti let) schopni vnímat ve svém volném čase hodnoty dobra, krásy nebo vyššího smyslu, eventuálně, $\mathrm{v}$ čem tyto hodnoty vidí a jak je popisují. Zvolili jsme členění volného času podle časových okruhů na volný čas denní, týdenní, roční a celoživotní (s ohledem na obor Pedagogika volného času, $\mathrm{v}$ jehož rámci se výzkum uskutečnil).

Základní výzkumná otázka vyplynula z cíle výzkumu:

Vnímají mladí lidé ve svém volném čase hodnoty dobra, krásy a životního smyslu, které je samé přesahují?

Z této základní otázky vyplynuly následující dílčí výzkumné podotázky:

1. Liší se nějak zkušenosti lidí ve věku mladé dospělosti s hodnotami krásy, dobra nebo vyššího smyslu v př́padě různých časových okruhů?

2. Jaké kategorie popisují jako ztělesnění hodnot krásy, dobra nebo smyslu?

3. Existují nějaké kategorie, které jsou všem okruhům zkoumaných hodnot společné?

Výzkum se uskutečnil prostřednictvím dotazníku obsahujícího pouze otevřené otázky týkající se bud' krásy, dobra nebo životního smyslu $\mathrm{v}$ běžném dnu, $\mathrm{v}$ předchozím týdnu, $\mathrm{v}$ předešlém roce a v celém životě tak, aby respondenti mohli skutečně vyjádřit celou šíri svých osobních prožitků. Tři dotazovaní odpovídali na otevřené otázky týkající se setkání s krásou, tři na otázky spojené s hodnotami dobra a tři na otázky zaměřené na hledání životního smyslu.

Zkoumali jsme výpovědi celkem devíti respondentů, vesměs absolventů TF JU, oboru Pedagogika volného času, pouze jeden muž absolvoval střední školu s učilištěm a jeden střední školu obchodního

17 Srov. () Petra HOŘEJŠÍ, Volný čas jako důležitý aspekt života pro hledání vyšších hodnot (dobro, krása, smysl) v 21. století, diplomová práce, vedoucí: Ludmila Muchová, České Budějovice: TF JU (on-line), dostupné na: file://C:/Users/Ludmila\%20M/Desktop/ Diplomova_prace_2018_Petra_Horejsi.pdf, s. 62-95, citováno dne18.6. 2018. 
ruchu. V každé trojici byl vždy zastoupen minimálně jeden muž a minimálně jedna žena. K analýze odpovědí respondentů jsme použili metodu otevřeného, axiálního a selektivního kódování.

Analýza odpovědí pomocí kódování: U jednotlivých respondentů jsme v textu nejprve identifikovali jednotlivé kódy, které jsme v podobě konceptů přiřadili ke dvěma kategoriím: příčiny zážitku a kritérium zážitku. Následně jsme v nich hledali další nadřazené kategorie. Pro účely této stati představujeme pouze nalezené nadřazené kategorie u jednotlivých respondentů.

\section{Respondentka č. 1:}

Vnímá své zkušenosti s krásou v kategorii vzájemná pozitivní mezilidská vztahovost, která je patrná v týdenním, celoročním a celoživotním volném čase. Trávení volného času s blízkými lidmi je pro ni velmi důležité. Tento bod se během dotazníku stupňuje od vnitřní pohody přes atmosféru v kruhu rodiny a lásky $\mathrm{k}$ díku za dar krásy v podobě rodiny a přátel. Další zkušeností s krásou je fascinace přírodou, která je patrná z denního, celoročního a celoživotního volného času. Tyto okamžiky jsou spjaté s harmonií s přírodou a jejím uchvácením v jakémkoli ročním období. Respondentka také reflektuje náplň svého zaměstnání jako setkání s krásou ve vztazích s dětmi. Jako důležité kritérium pro vnímání krásy zde přistupuje silný pocit darovanosti, jak v konkrétních okamžicích, tak ve vlastní schopnosti vnímat krásu.

\section{Respondent č. 2}

Vnímá své zkušenosti s krásou v kategorii, kterou bychom mohli nazvat souznění. Jde vlastně o určité vystupňování kategorie pozitivní mezilidská vztahovost směrem ke zdůraznění jednoty, intimity, harmonie, ale i ve vztahu ke zvíreti. Vedle toho popisuje pocity, které lze spojit do kategorie fascinace či uchvácení. Tyto pocity v něm vyvolávají jako důsledek radost.

Vzhledem k dennímu, týdennímu, celoročnímu a celoživotnímu volnému času můžeme zkonstatovat, že radost a klid $\mathrm{z}$ charakteristických pocitů spojených s radostí se prohubují v celoročním a celoživotním čase právě do fascinace a uchvácení. Pamatuje si v delším časovém horizontu to, co ho uchvátilo a fascinovalo, kdežto s každodenní zkušeností krásy spojuje méně intenzivní prožitky, jako je radost a klid.

\section{Respondentka č. 3}

Vnímá své zkušenosti s krásou v kategorii, kterou bychom mohli nazvat síla zážitku, který se projevuje v hrdosti na vlastní národnost a ve fascinaci přírodou - jako určitá síla zážitku. Mezi př́čcinami vjemu krásy zařazuje respondentka s různou intenzitou zážitky pozitivní mezilidské vztahovosti (vztah k novorozenci) a vnímání přírody.

\section{Respondentka č. 4}

Ve všech případech vnímá své setkání s dobrem v kategorii, kterou můžeme nazvat vzájemná pozitivní mezilidská vztahovost. V denní a týdenní zkušenosti jsou to spíše epizodické př́iběhy (pomoc přítele, atmosféra rodinné oslavy, na které si lidé dávají najevo lásku a sympatie). V celoroční zkušenosti už jde o hlubší reflexi, v níž dává respondentka do kontrastu anonymní a na efekt zaměřená média referující o člověku jako zlém a lidi žijící ze vzájemných hlubokých intimních 
vztahů lásky. V celoživotním čase respondentka reflektuje setkání s dobrem na úrovni, kterou lze nazvat kontemplací spojenou s krásou, ale také s pozorováním novorozeňat jako symbolů mravní čistoty. Ke kategorii vzájemná pozitivní mezilidská vztahovost přistupuje na této úrovni kategorie niternost.

Tyto dvě kategorie - vzájemná pozitivní mezilidská vztahovost a niternost - jsou pro respondentku rozhodující pro vnímání dobra jako bud’ spíše vnější pohody ve vztazích k lidem, nebo spíše niterné pohody ve vztahu k lidem, ale i k př́rodě a vesmíru.

\section{Respondent č. 5}

V denní zkušenosti vnímá své setkání s dobrem v kategorii vlastní pohody a vzájemné pozitivní mezilidské vztahovosti vnímané jako dobro, které uskutečňuí jemu blízcí lidé.

Dvě kritéria - osobní posun (at už směrem k lepším výkonům, nebo pozitivní vzájemnosti $\mathrm{k}$ začlenění do společnosti) a vzájemná pozitivní mezilidská vztahovost - jsou pro respondenta důležitým faktorem pro vnímání dobra ve svém životě, bud’ v rámci jeho vývoje $\mathrm{v}$ životě, nebo jako pracovního posunu. Vzájemná pozitivní mezilidská vztahovost se projevila v denním, celoročním a celoživotním období - ve vztahu k prŕtelkyni, sestře a společnosti, ovšem vždy jako dobro, které dělali druzí jemu.

\section{Respondentka č。 6}

V denní a týdenní zkušenosti vnímá setkání s dobrem v kategorii, kterou můžeme nazvat pohoda (at už vnější nebo vnitřní), a to i za vnímání kontrastu mezi špatnými událostmi a jejich dobrými důsledky.

Všemi odpověd’mi se táhne vnímání dobra jako vzájemné pozitivní mezilidské vztahovosti směřované od druhých lidí $\mathrm{k}$ respondentce. Její důsledky vnímá jako blaženost.

Tyto dvě kategorie - vzájemná pozitivní mezilidská vztahovost a blaženost - jsou pro respondentku důležité pro vnímání dobra, bud’ ve vztahu k lidem a jejich péče $\mathrm{k}$ její osobě nebo jako pocit blaženosti $\mathrm{k}$ lidem, věcem a př́rodě.

\section{Respondentka č. 7}

Respondentka vnímá své zkušenosti s životním smyslem jako součást vzájemných pozitivních mezilidských vztahů, tedy jako kategorii vztahovosti, ale vždy v souvislosti s nějakou další hodnotou: s vlastní osobitostí, niterností, pravdou, s majestátem smrti. Jedinečnou zkušenost s vyšším smyslem života činí především tam, kde se jedná o zcela výlučný vztah: manželský slib, umírající otec. Můžeme tedy zkonstatovat, že intenzita zkušenosti s životním smyslem roste u vzpomínek na celoroční a celoživotní události.

\section{Respondent č. 8}

Vnímá své zkušenosti s životním smyslem v kategorii vzájemná pozitivní mezilidská vztahovost, především se svou nukleární rodinou. Tato sféra se nachází ve všech oblastech volného času denním, týdenním, celoročním i celoživotním. V denním okruhu je pro respondenta důležité, aby měl spokojenou rodinu, která tráví čas spolu. $V$ týdenním okruhu je vidět uchvácení kojencem, jeho rozvojem. $\mathrm{V}$ celoroční se posouváme do oblasti vnitřní pohody a atmosféru lásky 
v kruhu rodiny a v celoživotním čase respondent vyjadřuje smysl svého života jako vědomí životního poslání.

Můžeme tedy zkonstatovat, že intenzita lásky $\mathrm{v}$ rodině roste $\mathrm{u}$ vzpomínek $\mathrm{v}$ rámci celoročního a celoživotního času, a to od popisu jedinečných událostí až po jasné vyjádření vědomí životního poslání.

\section{Respondentka č. 9}

Vnímá své zkušenosti s životním smyslem ve vztahu k novým životním rolím - manželka, budoucí matka. Kategorie vzájemná pozitivní mezilidská vztahovost je patrná ve všech časových okruzích. V denním volném čase je pro respondentku důležité, aby se dobře vyvíjelo její dítě. V týdenním volném čase je patrný pocit potřebnosti, který vyplývá ze setkání s bývalou kolegyní. $\mathrm{V}$ celoročním volném čase je nejdůležitějši posun k novým životním rolím a etapám, které zahrnují události jako stěhování, svatba, početí dítěte, péče o domácnost. V celoživotním volném čase respondentka reflektuje svůj dosavadní život a dobré i zlé zkušenosti jako výzvy k osobnímu růstu.

Na výzkumné otázky položené na začátku výzkumu jsme odpověděli následovně:

1. Vzhledem k otázce, zda se nějak liší zkušenosti lidí ve věku mladé dospělosti s hodnotami krásy, dobra nebo životního smyslu v př́ípadě různých časových okruhů:

U krásy a dobra roste intenzita popisovaných zkušeností vzhledem $\mathrm{k}$ dennímu, týdennímu, celoročnímu a celoživotnímu volnému času. U životního smyslu se zpřesňuje reflexe životní zkušenosti až k jasné formulaci principů, které dávají životní smysl.

2. Vzhledem k otázce, jaké kategorie popisují jako ztělesnění hodnot krásy, dobra nebo smyslu, můžeme sestavit jejich následující výčet:

Kategorie vztahující se k zážitku krásy:

- tváŕí v tváŕ pomíjivosti krásy;

- vnitřní pohoda;

- pocit darovanosti okamžiku;

- odpoutání od reality;

- vzájemná pozitivní mezilidská vztahovost (radost druhých);

- sounáležitost;

- harmonie s prŕrodou a městem;

- atmosféra okamžiku;

- fascinace - úžas;

- naplnění v práci;

- pocit štěstí;

- vědomí schopnosti vnímat krásu;

- nejkrásnější dar;

- vlastní radost a klid;

- pocit uchvácení;

- pocit souznění;

- síla okamžiku;

- vlastenectví.

Vzhledem k zážitkům s krásou vystupují do popředí kategorie jako fascinace či uchvácení, 
naplnění - spojené s atmosférou či pomíjivostí okamžiku, k němuž však vedle přírody hrají důležitou roli zážitky pozitivní mezilidské vztahovosti. Druhou osu kategorií tvoří vyjádření niternosti, štěstí nebo vnitřní pohody.

Kategorie vztahující se k zážitku dobra:

- vlastní pohoda (vnější i vnitřní);

- vzájemná pozitivní mezilidská vztahovost (dobro, které druzí dělají pro mě; udělat vše pro svoje děti; předávání „stopy dobra“; vzájemná důvěra a láska; starostlivost; péče; poctivost);

- niterná čistota (novorozeně);

- osobní posun v lepším podávání výkonů;

- materiální hodnoty;

- Životní posun směrem k začlenění do společnosti;

- darovanost času;

- blaženost.

Setkání s dobrem je zde spojováno především s kategoriemi pozitivní mezilidské vztahovosti vnímané jako dar, přicházející směrem od druhých lidí, prožívaný jako niterná čistota, blaženost nebo pohoda, ale také jako osobní duchovní růst.

Kategorie vztahující se k životnímu smyslu:

- niternost;

- vzájemná pozitivní mezilidská vztahovost;

- jedinečnost osobnosti;

- objev životní pravdy;

- potvrzení jedinečného mezilidského vztahu;

- majestát smrti;

- vzájemná pozitivní mezilidská vztahovost (vyjádřená jako ochota sdílet klid; schopnost žít samostatně a vytvořit domov druhým);

- láska směřující ke spokojenosti;

- niterný pocit;

- štěstí;

- radost;

- vědomí životního poslaní směřované na lásku k manželce a dětem;

- poznání originality vznikajícího života;

- pocit potřeby;

- vlastní potřebnost;

- souznění;

- osobní posun.

Setkání s životním smyslem je opět vnímáno ve vztahu k pozitivní lidské vzájemnosti, ale také zejména $\mathrm{k}$ duchovnímu růstu viděnému jako niternost, objev životní pravdy, nebo jako objev vlastního životního poslání.

3. Na otázku, zda existují nějaké kategorie, které jsou všem třem zkoumaným hodnotám v životech respondentů společné, můžeme odpovědět, že zde vystupuje do popředí především linie popisující pozitivní mezilidskou vztahovost na jedné straně, na straně druhé vlastní 
niternost, duchovní svět člověka, v němž prožívá vzhledem ke kráse fascinaci, úžas, štěstí, vzhledem $\mathrm{k}$ dobru pocit darovanosti, blaženosti, ale i vlastní duchovní růst (posun) a ve vztahu k životnímu smyslu je to směřování vlastního duchovního růstu k formulaci životní pravdy nebo životního poslání.

\section{Diskuse}

Závěry kvalitativního výzkumu nelze př́lišs rychle zevšeobecňovat. Jejich smysl spočívá spíše v diferencovaném popisu toho, jak mohou být určité jevy lidmi vnímány, prožívány a interpretovány. Což nevylučuje možnost, že jinými lidmi mohou být vnímány, prožívány a interpretovány jinak. $\mathrm{V}$ našem případě daly kategorie, které popisujeme, spíše konkrétnější a diferencovanější podobu filosofickým a psychoterapeutickým úvahám Patočky nebo Frankla. Přiblížily kategorie, ve kterých současní mladí lidé pojmenovávají své setkání s existenciálními hodnotami krásy, dobra a smyslu (což jsou kategorie pojmenované Franklem a částečně i Patočkou), tedy, jakou konkrétní podobu svého vnitřního duchovního světa vnímají ve vztahu k podnětům, které jsou díky tomu schopni vnímat v okolním světě.

Pro náboženského pedagoga je však také důležitá diskuse vedená otázkou, jaký význam mají taková zjištění pro výchovu obecně a náboženskou výchovu zvlášt. V odpovědi na takovouto otázku můžeme vyjít především z konfrontace těchto výsledků se samotným Maritainem. Zatímco v díle Integrální humanismus dospěl k nesmiřitelnosti pojetí humanismu antropocentrického, ateistického a integrálního humanismu teistického, křestanského, v díle Odpovědnost umělce můžeme nalézt poněkud jiný přístup, který se jeví v mnohem větším souladu s naším výzkumem. ${ }^{18}$ Je přirozeností člověka, ř́ká Maritain, že jedná svobodně a v touze po štěstí. Sám tedy určuje, jaké nejvyšší dobro bude ve skutečnosti jeho štěstím. Může se rozhodnout, že bude konat dobro ne pro svůj prospěch, ale z lásky $\mathrm{k}$ dobru jako takovému (např. tak, jak ho naši respondenti zažívali v mezilidských vztazích jako dar). Může mu i obětovat svo̊j život. At’ o tom ví či neví, vztahuje se $\mathrm{v}$ takové chvíli k dobru absolutně nejvyššímu, nekonečně transcendentnímu, to jest $\mathrm{k}$ Bohu. Maritain říká doslova: „Každý člověk, který se v prvotním úkonu svobody, zasahujícím svou hloubkou celou jeho osobnost, rozhoduje konat dobro z lásky k dobru, volí zároveň jako své nejvyšši dobro, vědomě nebo nevědomě, Boha. Miluje Boha více než sebe, i když nemá pojmové poznání Boha. " 19 To, že jako lidé toužíme po stavu blaženosti, a že ji dokážeme i v její přirozené podobě zažít, je známkou toho, že neexistujeme ve stavu pouhé přirozenosti. ${ }^{20}$ Podobně hovoří na jiném místě téhož díla o zkušenosti s krásou: „Již víckrát jsem řekl, že krása a poezie jsou neúprosné absolutno, jež vyžaduje úplné sebedarování a nestrpí žádné rozdělení. Dodejme ještě, že člověk se může úplně darovat dvakrát, pouze jde-li o Boha: prvně svému Bohu a podruhé něčemu, co je odrazem jeho Boha. " ${ }^{21}$ Ve světle těchto Maritainových výroků tedy můžeme vnímat hledání současného člověka v oblasti existenciálních hodnot jako je krása, dobro nebo smysl především jako - možná nevyslovenou - součást jeho hledání Boha, jednak můžeme rozumět ději, při němž půjde v křestanské výchově v první řadě o otevření člověka niternému světu, který (snad „zasypán“ totalitní ideologií komunismu) je prostorem, odkud se člověk vydává na cestu naplnění své touhy po štěstí tváří v tvář tajemství své existence ve světě. Skutečnost, že je také současný mladý člověk schopen se na

18 Srov. Jacques MARITAIN, Odpovědnost umělce, Praha: Triáda, 2011, s. 18-19.

19 MARITAIN, Odpovědnost..., s. 18.

20 Srov. tamtéž, s. 19.

21 Tamtéž, s. 94. 
takovou cestu vydat, a dokonce ji i popsat, ukázal náš výzkum. Teprve po takovémto otevření duchovní cesty člověka můžeme usilovat o její prohloubení k vědomí, že Boží milostí jsme povoláni nalézt krásu, dobro a smysl v jeho absolutním vyjádření - v Bohu a v naší účasti na jeho životě. Ostatně takové pojetí cesty $k$ Bohu současného člověka popisují i někteří fundamentální teologové jako napětí „,mezi imanentně lidským a transcendentně Božím“. Hodnoty jako krása, dobro nebo smysl vidí jako klíče k porozumění lidského a Božího, tedy jako klíče, které odemykají člověku prostor posvátného. Z Boží strany potom Bůh, který tvoří svět jako umělec - jeho slovo je tvůrčí, dobré a krásné, dává lidským dějinám také smysl v Kristu, protože skrze Něho, s Ním a v Něm veškeré stvoření ke svému smyslu dospěje. Krásu, dobro a smysl tedy tito teologové chápou jako cesty, po kterých si Bůh a lidé vzájemně kráčejí v ústrety. ${ }^{22}$

\section{Závěr}

Jak ukázal rozbor myšlenek J. Patočky a V. E. Frankla, i v životě současného člověka existují hodnoty, které přesahují jeho soustředěnost na pouhé uspokojení vlastní potřeb. Patočka se zaměřil především na hodnotu oběti, Frankl na hodnoty tvưrčí, zážitkové - krásy nebo lásky, a na hodnoty postojové - přijetí bolesti a utrpení v nemohoucnosti změnit vlastní osud. Existují tedy hodnoty, jejichž konkrétní výraz člověk vnímá, v rámci vlastního niterného života reflektuje - otevírá se jejich existenci a rozumí jim jako nové, duchovní kvalitě života. Následně přejímá zodpovědnost za vlastní př́spěvek $\mathrm{k}$ jejich rozvíjení ve formě vlastního utváření duchovní podoby své reakce na jejich existenci. Díky vlastnímu činu potom dává smysl svému životu jako duchovní podobě tohoto života. Křestanská víra se objevuje v životě člověka jako velmi významná v okamžiku, kdy vyslovuje svou víru v existenci smyslu celku světa jako nejvyššího smyslu, který mu dává Bůh zjevující se člověku v Kristu a v Duchu svatém.

Náboženská zkušenost představuje vážný fenomén $\mathrm{v}$ životě člověka, který je však nedostupný jak filosofické úvaze, tak úvaze psychoterapeutické. To, co ale spojuje chápání humanismu z pohledu křestanství a z pohledu člověka bez křestanské víry, je jejich hledání smyslu vlastního života založeného na setkání s duchovními hodnotami jako např. s krásou nebo láskou, kterým člověk přisuzuje cestu $\mathrm{k}$ naplnění života smyslem. Pro křestana je přitom významná garance této cesty ke smyslu až za hranice života samotným Bohem, $v$ něhož věří, který však člověka $z$ titulu víry nezbavuje odpovědnosti za morální kvalitu odpovědnosti za sebe a svět.

Přičemž náš výzkum ukázal na konkrétní podoby, v nichž setkání s hodnotami krásy, dobra a smyslu prožívá současný člověk bez křestanské víry. Za významné kategorie zde považujeme dvě velké oblasti: první se týká vnímání různých projevů pozitivní mezilidské vztahovosti, druhá otevření niterného, duchovního světa člověka, $v$ němž vnímá hodnoty krásy, dobra a smyslu ve spojení s fascinací, úžasem, štěstím, pocitem darovanosti, blaženosti, vlastního duchovního růstu, objevení životní pravdy nebo životního poslání. I jemu se tak otevírá cesta k Bohu, ve kterého neveř́í, a to skrze hodnoty, na které orientuje svůj život, za hranici vlastní „úživy“.

Pro křestanskou výchovu dětí a mladých lidí se tak nabízí cesta, na které nemusí sami sebe ve vztahu $\mathrm{k}$ neveřícím lidem vnímat jako jediné vlastníky pravdy tváří $\mathrm{v}$ tvář těm, kteří podlehli mylnému pokušení ateismu (ke kteréžto úvaze by mohlo vést Maritainovo srovnání křestanského teistického a ateistického člověkostředného humanismu), ale jako společné poutníky na cestě odhalování smyslu života a světa, o kterém je možné spolu hovořit, a to i s představením své

22 Srov. Ludmila MUCHOVÁ, František ŠTĚCH, Mezi lidským a Božím. Udržitelnost křestanské práce s mládeží v postsekulární Evropě, Studia theologica 2/2012, s. 1-12. 
vlastní - křestanské věřící cesty. Na druhou stranu mohou být nevěrící lidé, kteří projevují velkou otevřenost svého duchovního světa vůči hodnotám krásy a dobra a velkou odpovědnost vůči ono$\mathrm{mu}$ "problematickému smyslu“ (Patočka), výzvou pro pravdivost a statečnost věřících křestanů, zažívajících na své cestě ke „smyslu absolutnímu“ Boha jako zdroj krásy a dobra i jako svou posilu a doprovod na cestě hledání smyslu. Na troskách světa ničeného totalitními režimy plynoucími $\mathrm{z}$ antropocentrického humanismu, jak ho popsal Maritain, tak můžeme vnímat pokusy lidí o nový spirituální humanismus - humanismus cesty za smyslem.

\section{Kontakt}

doc. PhDr. Ludmila Muchová, Ph.D.

Jihočeská univerzita v Českých Budějovicích

Teologická fakulta, Katedra pedagogiky

Kněžská 8, 37001 České Budějovice

muchova@tf.jcu.cz

\section{Mgr. Petra Hořejší}

Jihočeská univerzita v Českých Budějovicích

Teologická fakulta, Katedra pedagogiky

Kněžská 8, 37001 České Budějovice 